\title{
Understanding Rural Change: Mobilities, Diversities, and Hybridizations
}

\author{
Luis Ca ma rero, J esús O liva
}

\begin{abstract}
Rural areas have experienced dramatic changes since the turn of the century, which has made it necessary to theorize their increasing diversity (exurban residential sprawl, international flows of labour, return migrations, neorurals, rural second homes, etc.). All these mobilities, including residential tourism, seasonal migrations, and long distance commuting, are changing not only the sociological composition of rural areas but the meanings of the analytical categories of the urban and the countryside, the global and the local, and residence and mobility, gradually turning them into what might be referred to as decentred categories. Furthermore, information and communication technologies and private automobility have completely changed rural life modes, affecting labour relations, social practices, and family strategies. Local authorities and rural institutions, policy makers and stakeholders, as well as researchers, today face a much more complex reality than imagined a few decades ago. Unexpected groups increasingly appear in unexpected places, and the cultural-ideological imaginary of post-modernity has multiplied the meanings of the rural - heritage, food, landscape, identity, etc. - and caused its commodification through emerging regional narratives and a new specialization in rural spaces. If classical rural studies analysed the immobility of the peasant world or its transformation through the process of urban-industrial modernization, today we explore the governance of rural hybridizations. Our analysis, carried out in different areas of rural Spain, shows that the cultural assimilation hypothesis is not able to explain new rural and hybrid lifestyles and the changes in rural livelihoods. On the contrary, we suggest that the impact of mobilities has increased the social and cultural diversity of rural areas. This paper re-examines the rural restructuring approach with the aim to theorize and include the process of hybridization in the rural debate.
\end{abstract}

KEY WORDS mobility, rural change, globalization, rural restructuring

\section{Introduction}

During the final decades of the 20th century, rural areas and populations experienced an acceleration in processes of modernization and transformation. Although these changes have been widespread, their consequences for rural areas have differed depending on the region. Originally, these processes - productive and residential dislocation, the deagrarianization of economic activity and the emergence of other, post-productive, activities and the ongoing breakdown between place of work and place of residence - were theorized from the perspective of rural restructuring. Recently, the consideration of the globalization of mobilities,

Sociální studia / Social Studies 2/2016. Pp. 93-112. ISSN 1214-813X. 
the integration of many regions into the international economy (for example, into agrifood industry chains, global tourism, and migration flows), and the increasing importance of mobility in social life have led to broader reflections on the role of rural regions within certain predominantly urban and transnational social processes. This line of research stresses hybridization, the capacity of rural areas to combine local and global processes.

Certainly the intensity and magnitude of the socio-economic changes that rural areas have experienced go beyond the simple notion of restructuring. This is not a mere adaptation to new circumstances, but rather a mutation of the role and nature of rurality. The social reality that rural authorities and institutions face today is unexpectedly as complex as that found in urban areas. In addition, the social actors involved in the governance of these areas are now more diverse than the traditional cast of local agents. To understand the implications of these changes, it is necessary to contextualize them through a theoretical approach that provides a relational vision. In what follows, we explore this possibility by analysing some of the processes that reveal their main consequences and that form the initial hypothesis of this study. We believe that the progressive hybridization of the rural world is the result of the impact of three forces of social change: the differentiation, globalization, and increased mobility of social life.

We analyse in separate parts of the paper these three supports (not causes) of rural hybridization (globalization, diversification, and mobilities). We begin this exploration with a number of theoretical considerations regarding the shift in analyses of rural change from perspectives focused on restructuring towards a debate emerging around globalization and hybridization. We then examine the direction of changes in the configuration of increasingly differentiated and diverse spaces and societies within a context of increasing mobility. The next section deals with the impact of different kinds of mobilities in the hybridization of the rural. In order to understand the scope of rural transformation, we follow an analytical strategy that contextualizes general processes of change in Mediterranean rurality, with Spain representing a clear example. We look at the process of deagrarianization and post-productive hybridization, globalization, as well as the increasing mobility and delocalization of social life. the final section focuses on the theoretical and analytical consequences implicit in these processes of rural change.

\section{From Restruc turing to Global Hybridization}

As the media and transportation have shaped an increasingly interconnected and smaller postglobal world (Harvey 1989b; Castells 1996) in which practically everything and everyone (capitals, work, information, elites, tourists, the displaced) seems to circulate with a fluidity that was unimaginable just a few decades ago (Urry 2000, 2006; Cresswell 2001, 2006), rural societies and spaces find themselves in unforeseen positions and places of socio-economic flow. the beginnings of this transformation and increasing interconnection between regional economies and new international divisions of labour were initially and suggestively theorized from a perspective of rural restructuring (Massey 1984; Rees 1984; Bradley and Lowe 1984; Urry 1984; Marsden 1987; Marsden et al. 1991).

Restructuring was an interpretive framework for understanding change that, as Lowe et al. (1990) then noted, provided a holistic approach to the reconfiguration of regional 
economies, particularly their labour markets and class structures, under the impact of new strategies of capitalist accumulation. Studies highlighted the dislocation of production resulting from exploiting regional inequalities through successive rounds of investment and divestment, cycles that reflected capital's capacity to resist local constraints, commitments, and regulations (Harvey 2006). As Massey explained (1984), the class composition of a specific place could be read as the result of the sum and combination of the roles played by its economy in changing divisions of labour on national and international levels. the rural world began in this way to become progressively integrated, although selectively, based on specific regional and social characteristics, into the new economic logic of disorganized post-Fordist capitalism (Lash and Urry 1987).

However, despite their early identification and interpretation of the sources and processes of rural transformation, these first approaches to restructuring emphasized the productive dimension and class relationships from an implicit determinism that gave little attention to other processes (Newby 1986), such as the new functions that the signs and representations of the rural exercised in its cultural re-evaluation, symbolic conflicts, and in exurban residential strategies (Morin 1973; Mormont 1983; Kayser 1990). Some of these issues would be addressed in a profusion of subsequent studies at the end of the last century, which, broadening perspectives on rural change, represented a true "cultural turn" in rural studies (Cloke 1997).

In addition, successive approaches that have analyzed the impact of globalization on spaces and localities also illustrate an evolution in analysis, in which rural areas, initially contemplated from a subordinate role, have more recently been seen as undergoing processes of gradual hybridization. The earlier studies focused on economic processes, productive flexibilization, tendencies towards deterritorialization, and spatial homogenization, all facilitated by new communication technologies. These global perspectives took into account the importance acquired by financial metropolises becoming global cities (Sassen 1991) and the nodes of an emerging space of flows (Castells 1996) dominated by the circulation of capital, information, and elites. However, other studies would shortly identify new global mobilities favoured by the cheapening of transport costs, such as global tourism and international labour migrations, or would follow more local approaches examining the cultural effects of globalization and the configuration of different transnational spaces (Appadurai 1996; Hannerz 1996). Lastly, more recent analyses have highlighted the need to consider all these interconnections as producers of truly translocal spaces (Brickell and Datta 2011) and ruralities (Hedber and do Carmo 2011). From this perspective, the rural world does not necessarily have a passive role in globalization but rather, "rural spaces, like villages, towns, and even the countryside can have the ability of attracting both demographic and economic fluxes on their own account, and they can incorporate some levels of centrality" (Hedberg and do Carmo 2010: 5).

Moreover, rural areas have not played a completely subordinate role in the reorganization of cycles of accumulation. The reformulation of productive activities revealed by rural restructuring can be understood as part of the geographic division of labour (Wallerstein 1974). Globalization differentiates regions and, therefore, local societies, through its division of production and consumption, but at the same time it links them within a logic of strong interdependence. Many rural areas have been integrated into chains of the global agri-food 
industry and seen their autonomy and their own organizational forms dissolved as they become integrated into much broader relations and organizations. In the framework of agrifood regimes (Friedman and McMichael 1989), we can see how rural regions are stripped of their local attributes as the management of their productive capacities and of their accumulation is taken over by outside agents. But these regions in turn must develop their organizational capacities in order to compete with other localities for their insertion into global processes. In this regard, we find ourselves within the reading of globalization proposed by Pieterse (1994), who emphasized structural hybridization as a mixture of modes of cooperative and competitive organization.

As Woods (2007) noted in relation to the current transformations taking place in rural areas through globalization, globalization itself is revealed to be the result of a negotiation in multiple dimensions (economic, natural, social, cultural).

There is no pre-existent stable and uniform rural place upon which 'globalization' can act, but then neither is there a single, unidirectional force of globalization. Rather the reconstitution of rural places under globalization must be understood as involving hybrid interactions at three levels. First, globalization is itself hybrid [...]. Second, globalization proceeds by hybridization [...]. Third [...] the countryside is a hybrid of the human and the non-human. (2007: 495)

\section{Rural Diversification}

Along with globalization, we can identify other interrelated processes that help us to understand increasing rural hybridization. First, the diversification of rural life stands out, the result of indeterminate processes, which as Pieterse (1994) noted, far from generating uniformity, adopt fluid and open forms. This is a structural hybridization that favours cultural and translocal mixtures. As Murdoch explained (2006) in his analysis of the constellations of networks that today structure the growing complexity of the rural world, the connections in which it is embedded "not only transport artefacts of various kinds rapidly through space but also serve to construct a variety of space-times in line with the precepts of each network alignment. Network complexity and spatial complexity therefore advance simultaneously" (2006: 172).

At the end of the 20th century, rural French geography began to point out that the problems of rural populations and areas were no longer very different from the general social and spatial problems faced by society (Hervieu 1993; Kayser 1990). Veltz (1996) was concerned with the effect that global economic restructuring first, and multi-dimensional globalization after, had on shaping French territory. He observed the paradox of a country becoming increasingly more homogeneous but also more fractured. The explanation for this apparent contradiction is found in the level of observation. On the one hand, territories are increasingly subject to major global processes that act jointly in all places. On the other hand, the responses at the local level to these macro-processes are increasingly diverse. Speaking metaphorically, Veltz refers to the "archipelago economy" to show the loss of continuity with which socioeconomic processes reach contiguous territories and to highlight the importance of the formation of networks and poles in shaping space. Veltz's work can be extrapolated to other European regions, and as a theoretical framework it allows us to understand current rural diversity and the formation of areas of a hybrid nature. 
On the one hand, we are faced with general processes that no longer differentiate rural areas from urban areas. For example, transnational migratory flows now arrive not only in urban centres but rural areas as well. On the other hand, however, the effect of these processes is very different in rural areas. Those rural areas that are closely connected to urban cores are able to take advantage of the availability of peri-urban labour power to establish food processing installations and connections with global agri-food chains. But in depopulated and aging rural areas, immigration is associated with the care economy (Camarero, Sampedro and Oliva 2011). At the same time, we also find that not only are there different effects in local economies, but local communities model these processes in different ways. Regarding immigration (Pedreño and Riquelme 2007; Oliva 2010; Sampedro and Camarero 2016), we find adaptations by nationality related to different tasks and regions. Woods (2016) analyzes the effect of globalization in 10 rural regions in the EU, which are focused on integration into different agri-food chains. He observes a wide diversity in the ways that similar territories integrate into global processes. In his conclusions, he sketches out the importance that institutional capacity, social capital, and local know-how play in this process. "It is the effectiveness or otherwise of such responses which structures the re-shaping of rural places under globalisation" (Woods 2016: 19).

Woods (2016) points out the importance of agreement and negotiation among local and external actors in terms of the impact of globalization on a region. Trabalzi and De Rosa (2011) draw the same conclusion: the long-term effect of development is not so much the result of the model or strategy followed - they compare a free market model with one based on public support - but on the connections established between local and external actors.

The homogenization of cultural and consumption processes weakens the specificity of forms of rural life and, therefore, the very homogeneity of the character of the rural. In contrast, it increases diversity as a result of a process of hybridization composed of the persistence of traditional rural elements with a mixture of distinct adaptive responses to global processes. This hybridization is also visible in the cultural dimension, but its substrate is clearly in socioeconomic processes. In this sense, we can also consider hybridization as an adaptive action and associate it with the issue of resilience.

The debate opened by Adger $(2000,2003)$ about resilience in socioecological systems has been applied to community systems, including rural ones, inserted into global environments. A broader conception of the meaning of social system, not focused on the isolated community, has led to a change in the focus of attention. There has been a shift from consideration of mere adjustment and adaptation to the environment to the complex idea of negotiation. Davidson (2010) explains it clearly; resilience must respond to complex social systems and must integrate the notion of agency. "The resilience framework directs our attention to information flows and cycles of change, exploring how our current institutions and connecting structures are likely to respond to disturbance" (p. 1146). Wilson (2012) incorporates the capacity of social capital to the economic and environmental; in this way we arrive at a continuum of responses that range from strategies of isolation and over-dependence on local resources and community capacities to a situation of over-globalization and loss of identity and autonomy. Skerrat (2013), in turn, looks at the question of agency and asks 
about its proactive capacity. In this sense, resilience is not only a response to an alteration but is also a way of steering change.

The idea of resilience permits us to see that processes of economic globalization are responded to agentially, but in a fractal form that is territorially based. The diversity of responses depends on the capabilities that each community deploys to reconcile the use of its resources and identity with external opportunities and accessibility. This process produces hybridization, and mixes levels of action (local, regional, transnational), modes and logics of production (peasant, capitalist), and times (pre-modern, modern, post-modern) (Pieterse 1994).

\section{Mobilities and Rural Change}

If the initial symptoms of rural restructuring were identified in the new mobility acquired by capital and later associated with migrations to rural areas by ex-urban groups, current hybridizations must be contextualized in the eclosion of mobilities that characterizes post-modern society (Urry 2006). As Murdoch suggests (2006), any analysis of the new patterns of rural differentiation must begin by considering the combined effects of the spatialization of counterurbanization and industrial dislocation. Or as Woods put it: "the social restructuring of rural areas has progressed in tandem with economic restructuring throughout the past century" (2005: 89). Successive migratory movements towards rural areas, such as exurban residential dispersion and the proliferation of second homes, have in this sense contributed to their ongoing sociological diversification (exurban middle classes, immigrants, returnees, neorurals, vacationers, etc.) (Kayser 1990; Urry 1995; Cloke and Little 1997; Milbourne 1997; Halfacreee 1994, 1998). And although studies of counter-urbanization managed to explain the initial movements towards rural areas, which were initiated at the end of the 1960s in the most industrialized countries by exurban middle classes, from the beginning of this century we have seen the gradual exhaustion of certain analytical categories, which are unable to account for new mobilities and migrations towards rural areas (Champion 2007; Mitchel 2004; Milbourne 2007; Halfacree 2008).

The progressive regional differentiation and sociological diversification of rural areas was amplified by the effect of the increasing globalization of mobilities around the turn of the century. As Williams (2009) noted, we found, with increasing frequency, new migratory movements bringing unexpected groups to unexpected places. Thus, the different international migrations to rural areas, whether related to work or residential-tourism (Bell and Osti 2010; Camarero et al. 2011; Halfacree and Rivera 2011), are shaping some of these rural localities into new rural melting pots (Oliva 2010); for example, in peri-urban regions, in coastal tourist towns, and in areas of intensive agriculture.

To understand the role that mobilities play in articulating territorial structures, it is necessary to analyze the combinations established between human and non-human agency; for example, to consider how the global chains of the agri-food industry are articulated with productive territories in systems that integrate corporations providing inputs (technology, seeds, fertilizers, etc.), international migrations (those who carry out harvests), research laboratories, local farmers, infrastructures, and transport systems. Rudy's analysis (2005) of the Imperial Valley in California as a cyborg territory is an example of these processes. 
In relation to daily mobility we must first consider the approach of Urry (2004) regarding the "system of automobility' as a phenomenon that combines political, social, productive, technological, and other non-human elements in a complex hybrid that determines not only forms of daily mobility but also relationships. This results in a system that produces a flexibility that acquires a coercive character. From a different perspective, the contribution of Young (2006), inspired by Actor-Network theory, allows us to also understand "distance" (and with it, the issue of mobility) beyond its material condition (as geographic distance), as a product that different hybridizations of natural, technological , and social aspects convert into a fundamental actor in rural economies.

This is a hybrid actor that, in a single territory, can establish unequal geometries for different social groups; for example, permitting the organization of global food distributors into a reliable order for the marketing and supply of goods across great distances through the integration of communications technologies, infrastructures, suppliers, warehousing, etc., against which local suppliers cannot compete, despite the advantage of being located "in situ". These are relationships that for Young lead the analysis to the substantial issue of the "hierarchies of connectivity' within increasingly network-based rural economies" (2006: 264).

The restructuring thesis revealed the growing impact of mobility on socio-demographic changes. But mobility (for example, seasonal and commuting) has also had effects on the shape of local identities. the interpretation of mobility as social practices, as proposed by Cresswell $(2001,2006)$, allows us to understand it in terms of a rural and urban connection. On the one hand, the high level of mobility between rural and urban areas produces a hybrid state that Hedberg and Carmo (2011) refer to as translocal. On the other hand, a continuous and repeated mobility makes differences disappear as the subject incorporates several simultaneous identities of belonging.

In an earlier study (Camarero and Oliva 2016), we explored, based on a small case study, the connections between mobilities and rural hybridization. Cases of rural residents who practiced rural to urban commuting were considered, as well as cases of the opposite movement. In addition, we analyzed different cases of bi-residentiality, composed of family groups that alternated residing in rural and urban settlements. This study identified a complex, seasonal, and cyclical mobility between rural and urban areas, understanding residential and work-related mobility as family strategies.

Our analysis highlighted the fluid nature of households. In a certain sense we see the weakening of the one-to-one correspondence between family group and home. To the extent that several residences are used, the forms of households become diverse. We found everything from cases that correspond to the so-called LAT (Living Apart Together) to other cases in which individuals alternated living in extended family with living in nuclear households to form a dense network of care and domestic exchanges based on multi-residential family structures.

As a consequence, many households were multi-residential. In this context, the categories of first and second residences are clearly obsolete. First, because the life perspectives of the subjects continually change the position between residences; but second, because the first and second residences exist within a context of almost daily travel, to such an extent that we can consider their housing to be cross-territorial. The cases studied 
showed us households that are urban and rural at the same time, workers who are urban and rural at the same time, and family groups that use networks of both rural and urban care. We also studied how individuals' life projects alternate between the country and the city. These cases exemplifying hybrid rurality illustrate the capacity of mobility to contribute to the diversification of rural life, but they also show us the importance of rural-urban differentiation in increasing mobility. the family and life strategies were based on taking advantage of different rural and urban characteristics to form strategies to maximize residential and work benefits.

We can see how settlement strategies, new forms of exclusion, and processes of local development seem to be especially related to mobility. In specific areas, local groups have over generations developed real cultures of mobility that with different space-time patterns connect local economies with labour markets or systems providing external services (seasonal migration, long distance commuting, dual residences). New information and communications technologies and the spread of automobility have in this sense radically changed the ways of life and strategies (family, labour, residential) of rural groups (Milbourne and Kitchen 2014; Camarero, Cruz and Oliva 2014).

Lastly, another support of rural hybridization is found in the impact of mobilities resulting from the new economies of signs and places (Lash and Urry 1994) that have emerged since the end of the last century and the strategies developed by regions and localities (place branding, rural marketing) competing to attract tourists and residents as well as activities and investments (Burguess 1982; Harvey 1989a). Postmodern ideological-cultural reconfiguration (Harvey 1989b) can be interpreted as a growing re-evaluation of the meanings associated with the rural. In this context, the appreciation of nature, landscapes and rural heritages and identities allows rural areas to increase their resources and their commodification (Perkins 2006).

However, the effect of the global tourism industry on the differential transformation of rural areas is mixed. On the one hand, the need to particularize an approach leads to increasing reflexivity on the specific meaning of the rural in each rural area. On the other hand, the need to adapt meanings and approaches to be understood and consumed by a massive "tourist gaze" (Urry 1990) often favours the replication of stereotypes, simulations, and the proliferation of what might be considered a generic rurality (Oliva and Camarero 2013), ways of differentiating that ultimately lead to the repetition and spread of a certain sameness.

\section{Deagranianization, Globalization, and Mobilities in Rural Spain}

In this section we illustrate the processes analysed with examples from the Spanish case. First, we explore deagrarianization and socioproductive hybridization. Then we analyse the impact of globalization in rural areas. Finally, we focus on the delocalization and mobilization of social life. The key to understanding the hybrid reality of rural societies in the Mediterranean is the radical transformation that has taken place in the forms and modes of economic activity and subsistence. From a historical perspective, the socioeconomic transformation of rural areas has been a continuous process of deagrarianization. 


\section{Deagrarianization and Socioproductive Hybridization}

We can define the processes of deagrarianization as the gradual loss of importance of the farming population in society, as well as the gradual dissolution of the centrality of agricultural activities in shaping rural lifestyles and forms of life. But deagrarianization does not refer to the abandonment or decline of farming; on the contrary, it is the result of the mutation, industrialization, and inclusion of agricultural production in a global agri-food system.

In the 1980s, Spanish agriculture became integrated into the market of what was then the European Economic Community. That decade is precisely considered the time of the emergence of what is referred to as the third agri-food regime, characterized by the regulation and management of agricultural production and accumulation by corporations to the detriment of national institutions (McMichael: 2005). Within this context, the Common Agricultural Policy (CAP) was reformulated and policies for rural development implemented. Under these policies, the reconversion of the agricultural sector was seen from the perspective of a series of structural improvements to foster the establishment of an industrial model of agriculture. While agricultural production was left in the hands of industrial groups, family farmers were asked to reduce their production, thus reducing the CAP's costs in subsidies, and freeing up funds for processes of rural development.

The process of rural deagrarianization is clearly associated with the gradual disappearance of agriculture based on family labour (Oliva and Camarero 2002), but this transition from a peasantry to modern family farming was not automatic. While a limited number of family farmers have been able to integrate into modern forms of commercial production, the vast majority of farms remain trapped in a logic that demands they supplement their income with other non-agricultural income. Growth in pluriactivity in the European context has become a sign of the emergence of an increasingly industrialized agriculture, which has lost its family-based character and, therefore, its connection to the local and regional area. In Spain, the data from the last census (2011) show that agricultural activities account for $12 \%$ of the overall occupations among rural inhabitants, a figure that is below that found in rural areas in the sectors of industry $(15 \%)$, construction $(13 \%)$ and commerce $(13 \%)$. Rural economies have diversified their economic activities, but families have also done so. Hybridization is not only regional, but it has also occurred within the domestic sphere. the data (2011 census) show that only $20 \%$ of Spanish farming households have at least two members dedicated to farming. This means that the dominant form of family farming is one in which only one member of the household works in farming, while the rest have other nonagricultural occupations.

Among the changes that the new agri-food regime has brought about, one that stands out is that agricultural production has become increasingly independent of rural populations. Two trends reveal this: one is the urbanization of those active in rural agricultural activities, and the other is the increasing use of agricultural workers of foreign origin. The initial decline of the family farm, followed by the decoupling of the local population from agriculture, are sources of the diversification and hybridization of rural identities, strongly supported by the new opportunities for mobility.

As we can see in Table 1, at the end of the 20th century, approximately two-thirds of persons working in agriculture resided in small, rural municipalities. Today, two decades 
later, rural localities account for less than half of all persons working in agriculture. This is due to the disappearance of family-based farm labour and the emergence of pluriactive rural households. Certain rural family groups organize their family strategies by prioritizing urban residency with its greater access to services and possibilities for non-agricultural employment. This is a new situation resulting from today's capacity for greater mobility.

Table 1: Distribution of persons working in agriculture by place of residence

\begin{tabular}{|l|c|c|c|}
\hline & $\mathbf{1 9 9 1}$ & $\mathbf{2 0 0 1}$ & $\mathbf{2 0 1 1}$ \\
\hline Rural & $67.3 \%$ & $55.4 \%$ & $48.5 \%$ \\
\hline Urban & $32.7 \%$ & $44.6 \%$ & $51.5 \%$ \\
\hline
\end{tabular}

Source: Population Census, Spanish National Statistics Institute

In addition, we find that since the beginning of this century there has been a significant increase in the number of foreign workers in agriculture. Today, they constitute more than one-fifth of agricultural workers ( $22 \%$ of those working in agriculture in the second quarter of 2015). Different studies have shown the high turnover among these workers. This foreign population does not manage to settle in rural regions or in the agricultural sector, and their employment and residential strategies are based upon mobility (Camarero, Sampedro and Oliva: 2011). Generally they opt for peri-urban residences that allow them to move about more easily so that they can combine seasonal and temporary work in agriculture, tourism, and construction.

These two processes - urbanization and the increase in foreign workers - reveal the definitive transformation of agricultural activity in terms of labour. On the one hand, we find farmers who commute in the opposite direction from what was habitual for workers/ peasants, commuting every day from urban residences to the country, to farms located in rural areas. On the other hand, we also find temporary, seasonal workers in agricultural jobs. These facts highlight the growing separation of agriculture from local labour markets and the way in which this activity translates its demand for labour to global markets. Agriculture no longer depends on the availability of local workers but rather competes like any other activity to attract temporary workers.

But we also find a shift in agricultural activity, which changes products and places in search of different market niches that produce a growing, differentiated consumption. Fresh produce from intensive agriculture processed by mechanized agribusiness (so-called 4th range products) and organic products are shaping new productive landscapes that take advantage of the proximity of consumers and markets in business strategies of an agriculture now detached from the rural environment.

\section{The Impact of G lobalization in Spanish Rural Areas}

The changes in farming previously analysed might be interpreted as the result of globalization processes. As Table 2 shows, we can consider, based on Input-Output models, that Spanish agriculture has become more and more dependent on the industrial sector, which 
is its main provider of inputs. Moreover, farming has become increasingly oriented towards exportation, reducing its impact on household consumption.

Table 2: Three indicators of agrarian activity

\begin{tabular}{|l|c|c|c|}
\hline & $\mathbf{1 9 9 5}$ & $\mathbf{2 0 1 1}$ & Growth (1995=100) \\
\hline Agrarian inputs from the industrial sector & $45.7 \%$ & $55.8 \%$ & 122.1 \\
\hline $\begin{array}{l}\text { Agrarian final consumption expenditure } \\
\text { by households }\end{array}$ & $28.3 \%$ & $25.0 \%$ & 88.3 \\
\hline Agrarian exportation & $14.9 \%$ & $25.3 \%$ & 169.8 \\
\hline
\end{tabular}

Source: Input-Output tables, WIOD databases

De-familiarization, salarization, and urbanization processes are the consequences of the adaptation of Spanish farming to the new context of global integration of the regions involved in the corporate food regime - an adaptation that implies a differentiation between farming and rurality.

The impacts of globalization on Spanish rurality can also be illustrated by the increasing importance of transnational migration flows in these areas. In the context of the new international division of labour, rural areas have attracted a labour force not just for farming but for all activities. The depopulation and aging of rural populations have favoured the settlement of an immigrant population. Chart 1 shows the weight of international migration during the first decade of the 21 st century.

Chart 1: Migratory balance in rural areas 1990-2014

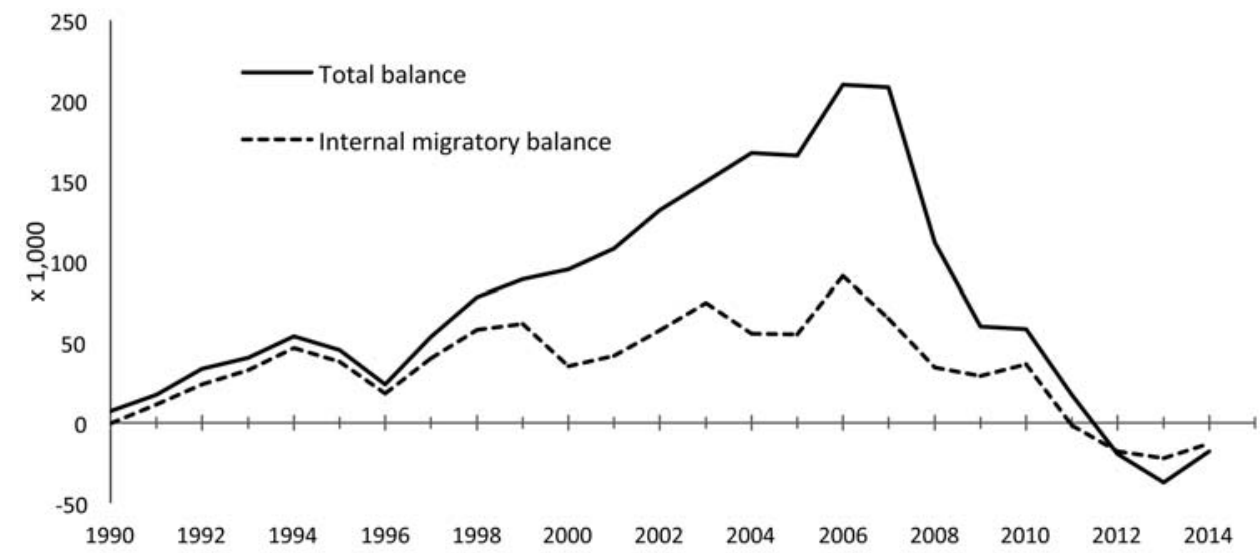

Source: Residential variations statistic from the Spanish National Statistics Institute

The difference between the total and internal migratory balance shows the importance of the new rural residents from abroad. Data also include a number, although small, of retired migrants from European countries. Both labour and retiree migrations are mobilities produced 
in a globalization context that involves an increase in social heterogeneity and diversification of rural areas.

\section{Deloc a lization and the Mobilization of Social Life}

Spanish rural areas have not only become more diversified, they are also highly interconnected. Two processes related to mobility have been fundamental in this sense to understand the functioning of rural areas in Spain: the significant daily movement of the population (commuting) and seasonal movement (based on second residences). The economically active rural population is highly dependent on extra-local labour markets. As shown in Chart 2, onethird of rural residents (between ages 25 and 50) who work, commute every day to an urban centre for their jobs. The proportion commuting daily is much higher among the youngest adults: $70 \%$ of young people between 18-20 years of age commute daily to urban centres for school and also, although to a lesser degree, for work.

Chart 2: Percentage of rural residents commuting to urban areas for work and/or education by age

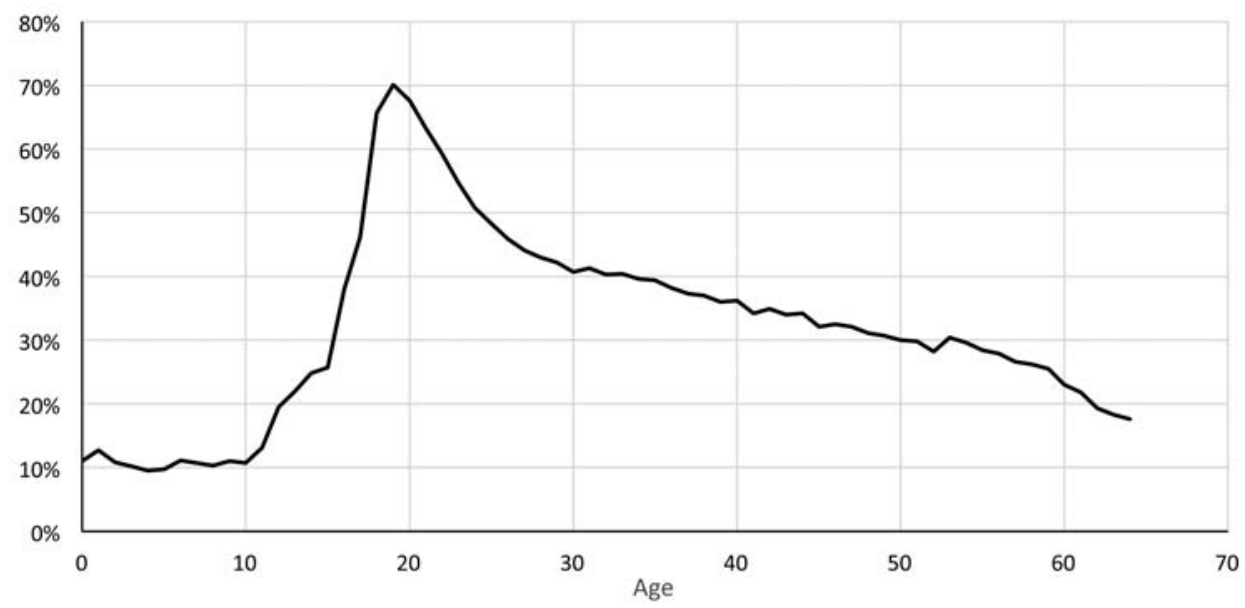

Source: Spanish Population Census 2011

Analysis of bi-directionality is important. The existence of mobility in the opposite direction turns out to be a central element within the logic of mobility as a force in hybridization. Thus, we also find urban residents who work in rural areas. In absolute terms, their numbers are limited compared to rural-urban commuting; however, in qualitative terms, it is a very significant phenomenon. As Chart 3 shows, in the 30-60 age group, $40 \%$ of those working in rural areas live in an urban area. In general, we can state the following in light of the data: Those who live in rural areas do not necessarily work there, and those who work in rural areas do not necessarily live there. 
Chart 3: Importance of urban residents in the rural labour market and education space

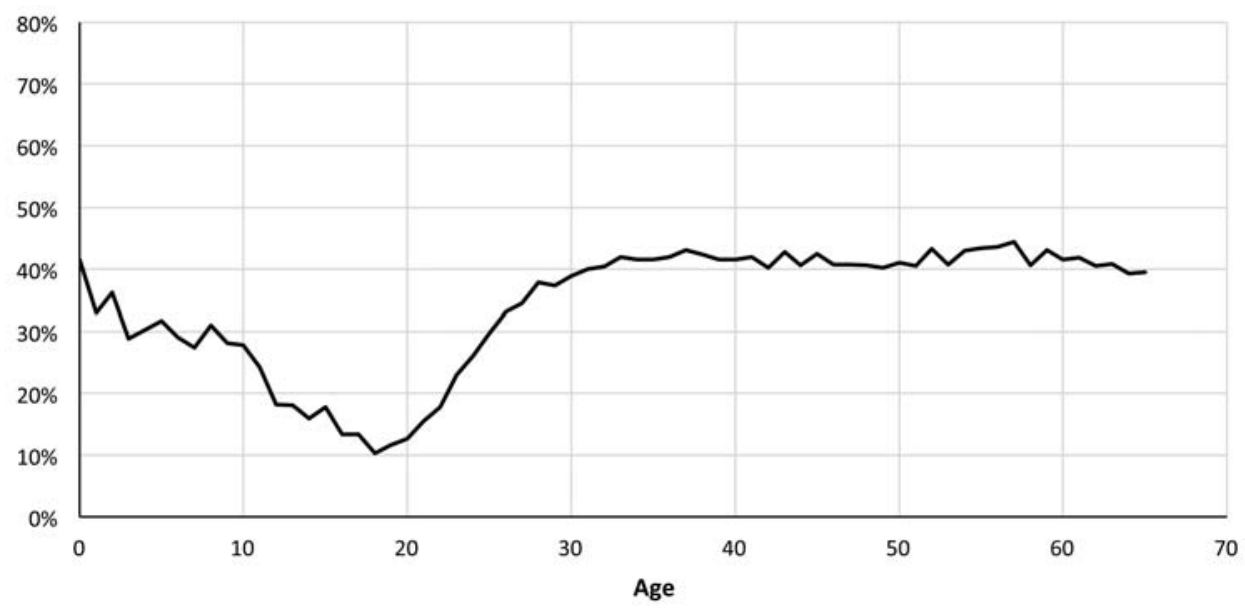

Source: Spanish Population Census 2011

Pendular mobility is therefore a key factor in the functioning of rural areas. Populations and economic activities no longer have to coincide in the same place, and as a result, local activities lose their capacity to determine the social structure of the local. This picture of the importance of mobility for social life is sharper if we consider the growth of different types of bi-residentiality, which originally referred to what were traditionally called first and second homes, with the latter used for vacations. In our case, what have been called second residences are simply those in which less time is spent during the year.

Charts 4 and 5 show the incidence of bi-residentiality, understood as the distribution of time between two residences. The data show that the 20-25 year old age group alternate between two residences quite frequently. Note that the average period of time spent in the "second home" in this age group is 70 nights per year, with 180 nights per year (half a year) being the maximum amount of time for the indicator. Older persons, already inactive or retired, also have a greater tendency toward bi-residentiality. In the case of young people, their behaviour, in which they alternate between the parental home and shared or individual housing, is associated with education and entry into the labour market. The case of the elderly is associated with seasonal variations - summer and winter - in residential behaviour.

It is important to stress that bi-residentiality does not merely refer to urban inhabitants going to rural areas on holiday (Del Pino: 2014). The data demonstrate the importance of second residences for rural inhabitants as well. The practice of bi-residentiality is neither rural nor urban, and thus, to the extent that it allows a mixing of and a belonging to more than one place, it has substantial importance as an element of hybridization. 
Chart 4: Average number of nights spent in second residence by habitat of residence and age

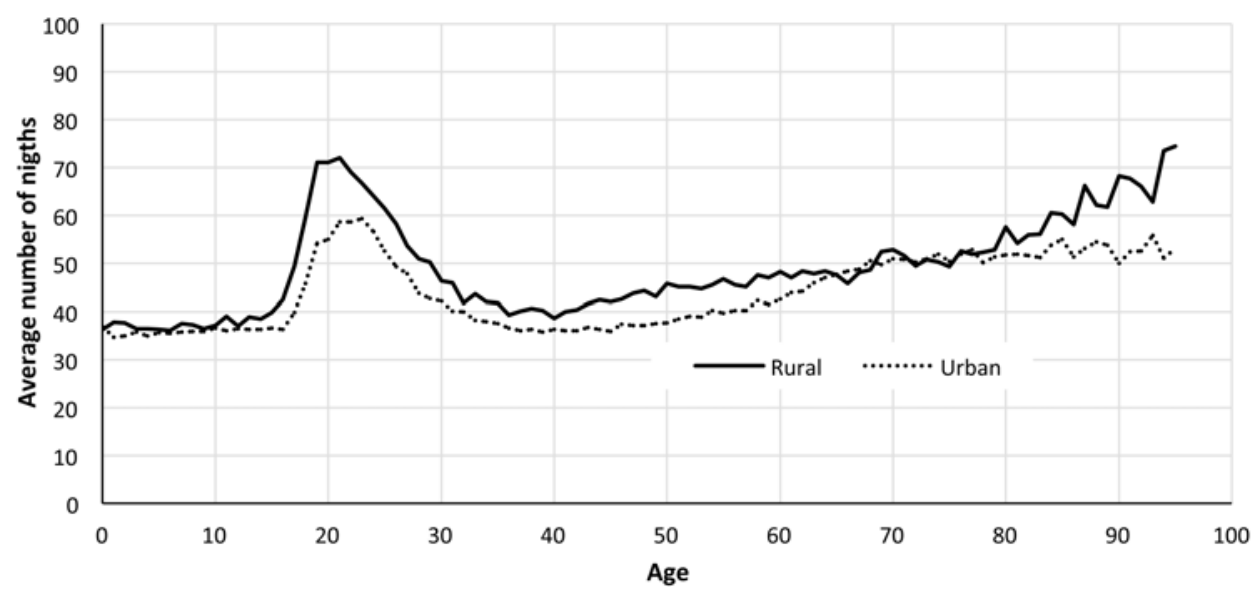

Source: Spanish Population Census 2011

The analysis of bi-residentiality in those cases that involve alternating between an urban and a rural residence enables us to clarify its nature. For rural inhabitants, there are two periods in life when there is more frequent alternation between dwellings: first, there is a period when young adults become independent and leave the parental home, generally between 18 and 30 years of age. The data show that young people from rural areas maintain the dual condition of being urban and rural residents, a key practice for understanding cultural hybridization. Later on, probably in many cases, they definitively reside in urban areas, but it is important to stress that deconnecting from the rural area is not abrupt, but takes place over a period of several years. In the case of individuals who are originally urban inhabitants, the proportion of bi-residentiality at younger ages is much more limited. However, it is also a reflection of a similar process: urban young people establishing themselves in rural areas but also maintaining a temporary link to their urban family residence.

At older ages, there is also an increase in bi-residentiality. We find two trends. First, there is the traditional urban-rural retirement. Urban residents between 60 and 80 years of age alternate residences, spending long periods of time at rural residences. More recent, but less studied, is the growing importance of bi-residentiality for rural inhabitants especially at ages over 80 . The explanation for this effect is the demand for care by the elderly population and thus, there is a the search, although perhaps seasonal, for greater proximity to hospitals and health care in urban areas. This often means staying in the homes of family members, generally of children, who reside in those urban areas. If in the case of young adults we find a link between their new home and the parental home, in this context, we are speaking of a bi-residentiality based on a link between elderly rural residents and their children's urban homes. 
Chart 5: Average number of nights spent in second residence outside habitat of first residence, by habitat and age

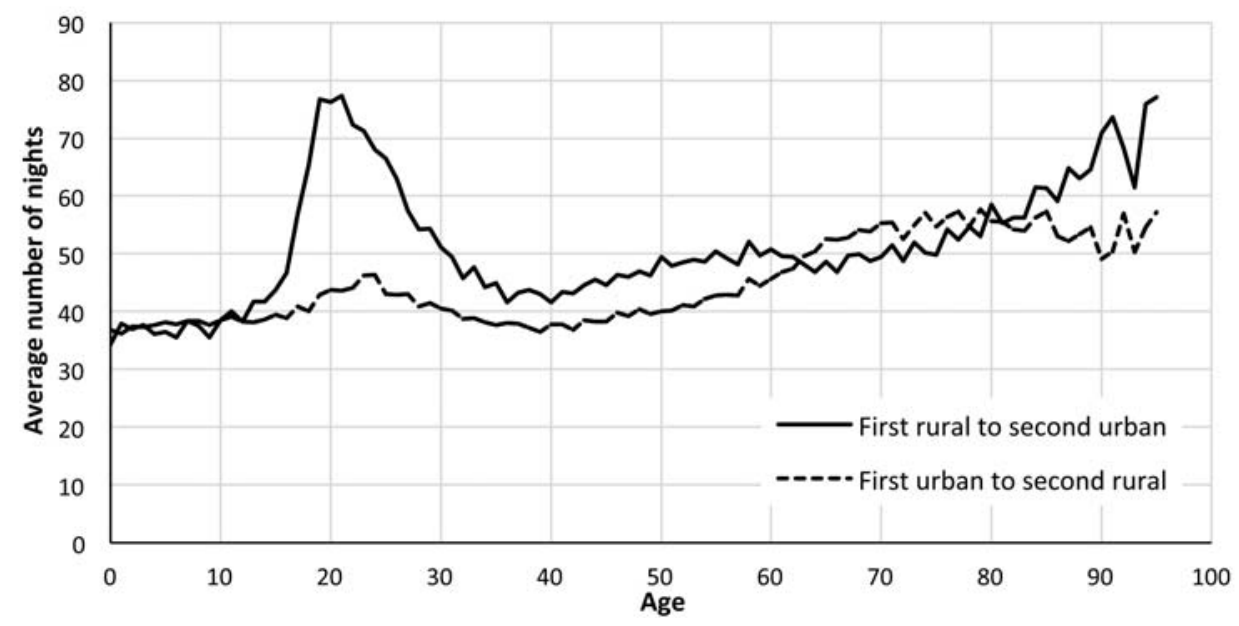

Source: Spanish Population Census 2011

\section{Conclusions}

In our analysis we have tried to conceptualize the transformation experienced by the rural world today, emphasizing the forces behind the changes, such as the globalization of mobilities, progressive regional differentiation, and sociological diversification, as well as the particular importance mobility has attained in social life. Figure 1 sums up the relations between these concepts previously discussed.

Our analysis of deagrarianization and socio-productive hybridization based on the examples studied in the Spanish case demonstrates the growing transnationalization, dislocation, and mobility of capital in its organization of productive processes and work. In particular, we have looked at the urbanization of persons employed in agriculture and the increasing use of foreign workers. In addition, the results from the study of daily and seasonal mobility reveal a rural world that does not tend towards differentiation from, or uniformity with, urban environments, but rather one that moves back and forth and creates hybrids between both environments.

If rural re-structuring decentred certain traditional meanings of the rural and the urban, of the agrarian and the industrial, the impact of the hybridizations experienced today by a rurality that is increasingly more complex and transnational, has progressively expanded this erosion of the analytical categories associated with residence and mobility, the global and the local, identity and belonging. At the same time as these rural realities are being shaped into translocal societies and regions, their quality of life and the revitalization of their structures (economic, demographic, etc.) increasingly depend on how their hybridizations, their sociological diversification, and mobilities are articulated in rural government policies and in the local cultures themselves. 
Figure 1: Relations between globalization, differentiation and mobilities

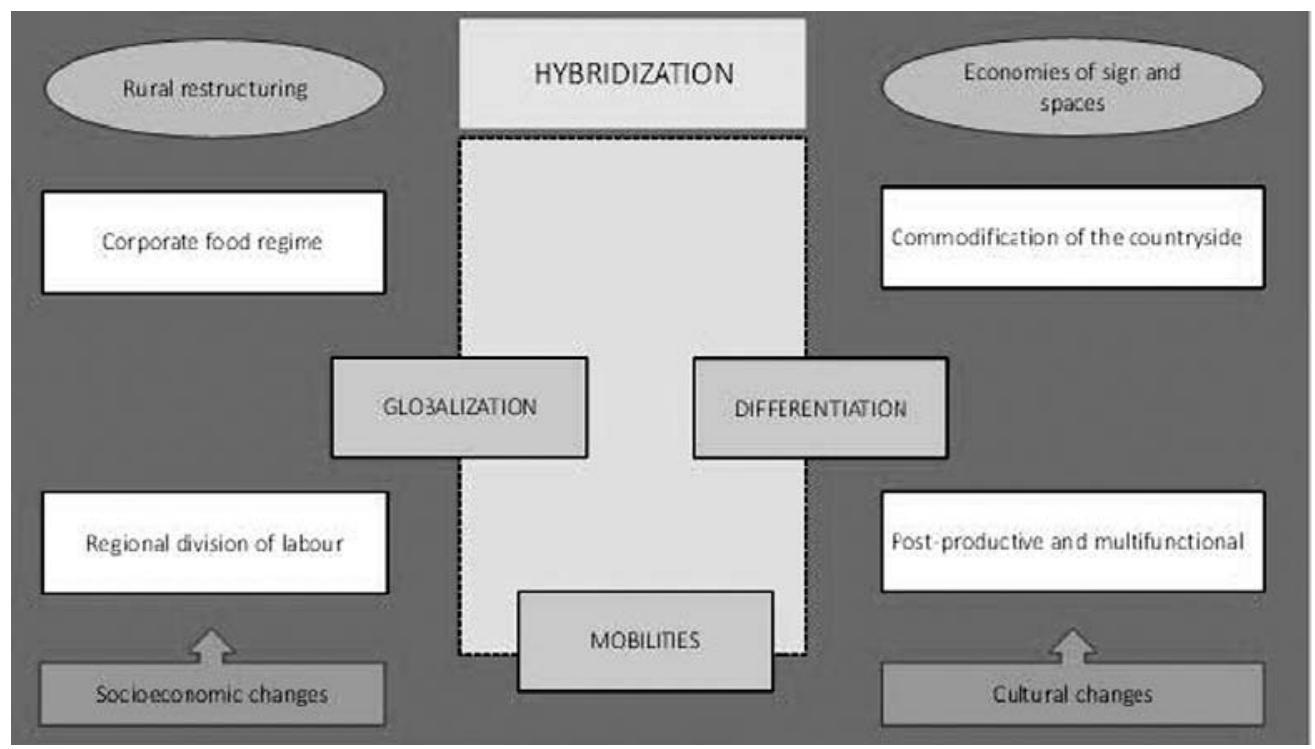

Our exploration leads us to a different observation and conceptualization of rurality. In general, studies have tried to either establish a clear differentiation between the rural and the urban or they have considered the existence of degrees of transition between the rural and the urban, as if on a continuum (Sorokin and Zimmerman 1929). Both perspectives lead to an interpretation of the processes of change as a gradual urbanization of rural areas and the marginalization of the ways of rural life as small pockets of resistance to change and modernization. The study carried out here leads to a different approach. Today we do not see pure forms of either rural or urban life. What we observe instead are increasingly hybrid processes made up of different degrees of urban and rural logics. This hybridization is not a process of unification, convergence, or of a simple mixture of cultural forms; on the contrary, it is based on growing diversification and differentiation.

The new approaches in geography based on rural hybridization have managed to transcend the old perspectives on place as something static, instead conceptualizing it as a reality being continuously reconstituted by flows (of information, persons, objects). As Woods suggests, "examining the performance of rurality enables the research to move away from thinking of the rural as a spatially fixed entity and focus on the way in which rurality (or particularly ways of being rural) is embedded in social practices" (2005: 302). Sociological analysis also allows us to look at rural mobility and hybridization through processes and social actors. Considering the latter not as entities fixed in terms of region, belonging, or identity, but rather as groups that integrate in all these relations the fluidity of the times, the spaces, and the social practices characteristic of different social worlds (rural, urban, translocal).

Today it seems necessary to go beyond the categories that sought to establish the coordinates of static traditional societies, to deepen our understanding of fluid experiences between 
different referents and social worlds. As we have tried to show, it is not only that we are witnessing a growing sociological diversification of rural populations, but the majority of them appear to be both continuously mobile and hybrid. For example, as we have shown, individuals combine forms of commuting, of residence, of work, and family responsibilities to build changing personal projects throughout their life cycles based on these hybridizations and mobilities; that is, not according to the traditional definitions of settlement or migration, but based on the new space-time frames and paths of post-modern society.

\section{References}

ADGER, W. Neil. 2000. "Social and Ecological Resilience: Are They Related?" Progress in Human Geography 24(3): 347-364.

ADGER, W. Neil. 2003. "Social Capital, Collective Action and Adaptation to Climate Change." Economic Geography 79(4): 387-404.

APPADURAI, Arjun. 1996. Modernity at Large: Cultural Dimensions of Globalization. Minneapolis: University of Minnesota Press.

BAUMAN, Zygmunt. 2000. Liquid Modernity. Cambridge: Polity Press.

BELL, Mikel and Giorgio OSTI. 2010. "Mobilities and Ruralities: An Introduction." Sociologia Ruralis 50(3): 200-204.

BRADLEY, Tony and Philip LOWE, eds. 1984. Labour and Locality. London: Norwich.

BRICKELL, Katherine and Ayona DATTA. 2011. Translocal Geographies: Spaces, Places, Connections. Aldershot: Ashgate.

BURGUESS, Jacquelin. 1982. "Selling Places: Environmental Images for the Executive." Regional Studies 16(1): 1-17.

CAMARERO, Luis, Fátima CRUZ and Jesús OLIVA. 2014. "Rural Sustainability, Inter-generational Support and Mobility.” European Urban and Regional Studies 23(4): 734-749.

CAMARERO, Luis and Jesús OLIVA. Forthcoming. "Social Inequalities Across Unbalanced Territories in Rural Spain." Portuguese Journal of Social Sciences.

CAMARERO, Luis, Rosario SAMPEDRO and Jesús OLIVA. 2011. "Foreigners, Neighbours, Immigrants: Translocal Mobilities in Rural Areas in Spain.” Pp. 155-176 in Translocal Ruralism: Mobility and Connectivity in European Rural Spaces, edited by Charlotta HEDBERG and Renato Miguel DO CARMO. London: Springer.

CASTELLS, Manuel. 1996. The Rise of the Network Society. Cambridge, MA: Blackwell.

CLOKE, Paul. 1997. "Country Backwater to Virtual Village? Rural Studies and 'the Cultural Turn'." Journal of Rural Studies 13(4): 367-375.

CLOKE, Paul and Jo LITTLE, eds. 1997. Contested Countryside Cultures: Otherness, Marginalisation and Rurality. London: Routledge.

CRESSWELL, Tim. 2001. "The Production of Mobilities.” New Formations 43: 11-43.

CRESSWELL, Tim. 2006. On the Move: Mobility in the Modern Western World. New York: Routledge.

DAVIDSON, Debra J. 2010. "The Applicability of the Concept of Resilience to Social Systems: Some Sources of Optimism and Nagging Doubts." Society \& Natural Resources 23(12): 1135-1149.

DEL PINO, Julio Artacho. 2014. “Sociología de la residencia y residencia móvil: logros teóricos y límites prácticos.” Empiria 27: 21-48.

ETXEZARRETA, Mirren E. and L. VILADOMIÚ. 1997 “El avance hacia la internacionalización: Crónica de una década de la agricultura española." Pp. 317-354 in Agricultura y Sociedad en la España Contemporánea, edited by Benito GÓMEZ and J. GONZÁLEZ. Madrid: CIS-MAPA. 
FRIEDMAN, Harriet and Philip McMICHAEL. 1989. "Agriculture and the State System: The Rise and Decline of National Agricultures, 1870 to the Present." Sociologia Ruralis 29(2): 93-117.

HALFACREE, Keith. 1994. "The Importance of 'the Rural' in the Constitution of Counterurbanisation: Evidences from England in the 1980s." Sociologia Ruralis 34(2-3): 164-189.

HALFACREE, Keith. 1998. "Neo-tribes, Migration and the Post-productivist Countryside.” Pp. 200-214 in Migration into Rural Areas: Theories and Issues, edited by Paul BOYLE and Keith HALFACREE. John Wiley: Chichester.

HALFACREE, Keith. 2008. "To Revitalize Counterurbanization Research? Recognizing an International and Fuller Picture.” Population, Space and Place 14(4): 479-495.

HALFACREE, Keith and María J. RIVERA. 2011. "Moving to the Countryside... and Staying: Lives Beyond Representations." Sociologia Ruralis 52(1): 92-114.

HANNERZ, Ulf. 1996. Transnational Connections: Culture, People, Places. London: Routledge.

HARVEY, David. 1989a. "From Managerialism to Entrepenurialism: The Transformation of Urban Governance." Geographiska Annaler 71B(1): 3-17.

HARVEY, David. 1989b. The Condition of Postmodernity: An Enquiry into the Origins of Cultural Change. Oxford: Basil Blackwell.

HARVEY, David. 2010. The Enigma of Capital: And the Crises of Capitalism. London: Profile Book.

HEDBERG, Charlotta and Renato M. DO CARMO. 2011. Translocal Ruralism: Internal and International Mobilities in European Rural Space. London: Springer.

HERVIEU, Bertrand. 1993. Les champs du futur. Paris: F. Bourin.

KAYSER, Bernard. 1990. La renaissance rurale: Sociologie des campagnes du monde occidental. Paris: Armand Colin.

LASH, Scott. and John URRY. 1987. The End of Organized Capitalism. Cambridge: Polity Press.

LASH, Scott. and John URRY. 1994. Economies of Signs \& Space. London: SAGE.

LOWE, Philip, Terry MARSDEN and Richard MUNTON. 1990. The Social and Economic Restructuring of Rural Britain: A Position Statement. ESRC Countryside Change Working Papers Series, 2, U.C.L.

MARSDEN, Terry. 1987. "Exploring a Rural Sociology for the Fordist Transition: Incorporating Social Relations into Economic Restructuring.” Sociologia Ruralis 32(2/3): 209-230.

MARSDEN, Terry, Philip LOWE and Sarah WHATMORE. 1990. Rural Restructuring: Global Processes and Their Responses. London: David Fulton Publishers.

MASSEY, Doreen. 1984. Spatial Divisions of Labour: Social Structures and the Geography of Production. London: MacMillan.

McMICHAEL, Philip. 2005. "Global Development and the Corporate Food Regime." Research in Rural Sociology and Development 11: 269-303.

MILBOURNE, Paul. 2007. "Re-populating Rural Studies: Migrations, Movements and Mobilities." Journal of Rural Studies 23(3): 381-386.

MILBOURNE, Paul and Lawrence KITCHEN. 2014. "Rural Mobilities: Connecting Movement and Fixity in Rural Places.” Journal of Rural Studies 34: 326-336.

MITCHELL, Clare J. A. 2004. "Making Sense of Counterurbanization.” Journal of Rural Studies 20(1): $15-34$.

MORIN, Edgar. 1973. “L'Ecologie de la civilisation technicienne.” Pp. 45-75 in Une Nouvelle civilisation: Hommage à Georges Friedmann. Paris: Galimard.

MORMONT, Marc. 1983. "The Emergence of Rural Struggles and Their Ideological Effects." International Journal of Urban and Regional Research 7(4): 559-575.

MURDOCH, Jonathan. 2006. "Networking Rurality: Emergent Complexity in the Countryside." Pp. 171-184 in Handbook of Rural Studies, edited by Paul CLOKE et al. London: SAGE. 
MURDOCH, Jonathan, Philip LOWE, Neil WARD and Terry MARSDEN. 2003. The Differentiated Countryside. London: Routledge.

NEWBY, Howard. 1986. "Locality and Rurality: The Restructuring of Rural Social Relations." Regional Studies 20(3): 233-242.

OLIVA, Jesús. 2010. "Rural Melting-pots, Mobilities and Fragilities: Reflections on the Spanish Case." Sociologia Ruralis 50(3): 277-295.

OLIVA, Jesús and Luis CAMARERO. 2001. "Shifting Rurality: The Spanish Countryside after De-peasantisation and De-agrarianisation.” Pp. 219-237 in Europe's Green Ring, edited by Leo GRANBERG, Imre KOVÁCH and Hilary TOVEY. Aldershot: Ashgate.

OLIVA, Jesús and Luis CAMARERO. 2013. "Touristic Processes, Generic Rurality and Local Development." Pp. 19-42 in Fertile Links? Connections Between Tourism Activities, Socioeconomic Contexts and Development in European Rural Areas, edited by Elisabete FIGUEIREDO and Antonio RASCHI. Florence: Firenze University Press.

ORTI, Alfonso. 1997. "Una vision histórica generalista de la sociología agraria en España: las tres modernizaciones del desarrollo capitalista." Pp. 71-105 in Agricultura y Sociedad en la España Contemporánea, edited by Benito GÓMEZ and J. GONZÁLEZ. Madrid: CIS-MAPA.

PEDREÑO, Andrés and Prudencio J. RIQUELME. 2007. "La condición inmigrante de los nuevos trabajadores rurales.” Revista Española de Estudios Agrosociales 211: 189-238.

PERKINS, Harvey. 2006. "Commodification: Re-resourcing Rural Areas.” Pp. 243-257 in Handbook of Rural Studies, edited by Paul CLOKE et al. London: SAGE.

PIETERSE, Jan N. 1994. “Globalisation as Hybridisation.” International Sociology 9(2): 161-184.

REES, Gareth. 1984. "Rural Regions in National and International Economies.” Pp. 389-406 in Labour and Locality, edited by Tony BRADLEY and Philip LOWE. London: Norwich.

RUDY, Alan P. 2005. “Imperial Contradictions: Is the Valley a Watershed, Region, or Cyborg?” Journal of Rural Studies 21(1): 19-38.

SAMPEDRO, Rosario and Luis CAMARERO. 2016. "International Immigrants in Rural Areas: the Effect of the Crisis in Settlement Patterns and Family Strategies." Pp. 148-149 in Proceedings of the XXVI Congress: Places of Possibility? Rural Societies in a Neoliberal World. Retrieved September 5, 2016 (http://esrs2015.hutton.ac.uk/sites/www.esrs2015.eu/files/FINAL\%20ESRS\%20 Congress\%20Proceedings.pdf).

SASSEN, Saskia. 1991 The Global City: New York, London, Tokyo. Princeton, NJ: Princeton University Press.

SKERRATT, Sarah. 2013. "Enhancing the Analysis of Rural Community Resilience: Evidence from Community Land Ownership.” Journal of Rural Studies 31: 36-46.

SOROKIN, Pitirim A. and Carle C. ZIMMERMAN. 1929. Principles of Rural-Urban Sociology. New York: Henry Holt.

STOCKDALE, Aileen and Marsaili MacLEOD. 2013. "Pre-retirement Age Migration to Remote Rural Areas." Journal of Rural Studies 32: 80-92.

TRABALZI, Ferruccio and Marcello DE ROSA. 2011. "Market and State-supported Sustainability: A Tale of Two Rural Communities in Iowa and Italy." Sociologia Ruralis 52(1): 115-133.

VELTZ, Pierre. 1996. Mondialisation, villes et territories: L'économie d'archipel. Paris: Presses Universitaires de France.

URRY, Joh 1984. "Capitalist Restructuring: Recomposition and the Regions.” Pp. 45-64 in Locality and Rurality, edited by Tony BRADLEY and Philip LOWE. London: Norwich.

URRY, John. 1990. The Tourist Gaze: Leisure and Travel in Contemporary Society. London: SAGE.

URRY, John. 1995. “A Middle-class Countryside?” Pp. 205-219 in Social Change and the Middle Classes, edited by Tim BUTLER and Mike SAVAGE. London: University College London Press.

URRY, John. 2004. “The 'System' of Automobility.” Theory, Culture \& Society 21(4/5): 25-39. 
URRY, John. 2006. “The New Mobilities Paradigm.” Environment and Planning A 38: 207-226.

WILSON, Geoff A. 2012. "Community Resilience, Globalization, and Transitional Pathways of Decision-making." Geoforum 1218-1231.

WOODS, Michael. 2005. Rural Geography: Processes, Responses and Experiences in Rural Restructuring. London: SAGE.

WOODS, Michael. 2007. "Engaging the Global Countryside: Globalization, Hybridity and the Reconstitution of Rural Space.” Progress in Human Geography 31(4): 485-507.

WOODS, Michael. 2016. "Economic Entanglements and the Re-shaping of Place in the Global Countryside.” Pp. 11-32 in Regional Resilience, Economy and Society: Globalising Rural Places, edited by Christine TAMÁSY and Javier REVILLA. New York: Routledge.

WALLERSTEIN, Immanuel. 1974. The Modern World-system: Capitalist Agriculture and the Origins of the European World-Economy in the Sixteenth Century. New York: Academic Press.

WILLIAMS, Allan M. 2009. "International Migration, Uneven Regional Development and Polarization." European Urban and Regional Studies 16(3): 309-322.

YOUNG, Nathan. 2006. "Distance as a Hybrid Actor in Rural Economies." Journal of Rural Studies 22(3): 253-266.

\section{Authors}

Luis Camarero is Professor at the Department of Theory, Methodology and Social Change, Faculty of Political Science and Sociology, National Distance Education University in Madrid. His research work is focused on the analysis of socioeconomic trends and living conditions in rural areas in Spain and Europe. He has participated in several research projects related to gender inequalities, demographic issues and labour markets. He is currently interested in the role spatial mobilities play in the transformation of social structure and demographic composition of rural areas.

Contact: 1camarero@poli.uned.es

Jesús Oliva is Senior Lecturer at the Department of Sociology, Faculty of Human and Social Sciences, Public University of Navarre in Pamplona. His main research interests have been in the sociology of mobility, rural restructuring, urban sociology and planning. He has published various texts on urban mobility, rural commuting, labour markets and landscape planning. Currently, he is conducting a three years research project on the impact of mobilities (migrations, tourism, commuting, residential moves) in rural areas and the increasing role they play for their social sustainability.

Contact: jesus.oliva@unavarra.es 